\title{
Koncepce evolutivního výkladu \\ - metodologické ukotvení interpretační techniky
}

\section{A Concept of Evolutive Interpretation - Methodological Anchoring of the Interpretative Technique}

\author{
Michal Malaník*
}

\begin{abstract}
Abstrakt
Tento článek se zamèruje na koncepci evolutivního (nebo také evolučního) výkladu právních textü. V našem právnim prostrédi použiváme obecně známé metody právni interpretace, mezi keteré interpretace evolutivní nepatri. Tento clánek ukazuje, co evolutivni výklad právního textu je, jaké jsou jebo základni znaky a uvádí je do kontextu s kontinentálnimi a anglo-americkými prístupy. Clánek tedy slouři jako pozvánka k hlubsímu teoretickému poznáni tohoto interpretaćníbo nástroje.
\end{abstract}

Klíčová slova

interpretace práva; metodologie; evolutivni výklad; interpretačni techniky; mezinárodni soudy; textualismus; intencionalismus; účel právního textu.

\begin{abstract}
This paper aims on the evolutive (or evolutionary) interpretation of legal texts. In our legal background we use generally known methods of legal interpretation to which the evolutive interpretation does not belong. This paper shows what the evolutive interpretation of legal texts is, what are its main features, and puts it into context with continental and anglo-american methodological approaches. It thusly serves as an invitation to proper theoretical understanding of this interpretative tool.
\end{abstract}

\section{Keywords}

Interpretation of law; Methodology; Evolutive Interpretation; Interpretative Techniques; International Courts; Textualism; Intentionalism; Purpose of a Legal Text.

\section{Slovo úvodem}

Často se stává, že se názory právních teoretiků s názory praktických právníků neshodují. Důvodů může být několik. Bud’ teorie potřebuje reagovat na vývoj, kterým právo jako takové neustále prochází a změnit se, nebo naopak praxe musí reflektovat metodologické principy, které teorie poskytuje a neobracet jejich význam bez významnějšího důvodu. Takovým důvodem může být např. nová skutečnost, která odlišuje doposud uznávaný a používaný koncept od něčeho, co praxe potřebuje nově nazvat. To obzvláště

\footnotetext{
* JUDr. Michal Malaník, doktorand, Katedra právní teorie, Právnická fakulta Masarykovy univerzity, Brno / Ph.D. student, Department of Legal Theory, Masaryk University, Brno, Czech Republic / E-mail: michmal@mail.muni.cz
} 
platí pro situace, kdy se praxe snaží pojmenovat nový metodologický nástroj, protože cítí potřebu doplnit ne tak dynamicky reagující právní teorii. Jedním z takových témat může být právě otázka evolutivního výkladu práva.

Evolutivní (nebo také evoluční) výklad práva se stává v posledních letech čím dál častěji diskutovaným tématem a používaným nástrojem při interpretaci práva, zejména pak na úrovni mezinárodních soudů. Tento článek si dává za úkol poukázat v základu na to, co to vlastně evolutivní výklad je, na jakých základech stojí, které prvky v sobě obsahuje a také - je-li žádoucí, aby se tato technika používala ve smyslu, ve kterém ji nyní interpretační komunita chápe. Tedy jinými slovy - je-li koncept evolutivního výkladu ustálený a obsahuje dostatečné množství odlišujících znaků od jiných typů výkladu na to, aby mohl být považován za nový metodologický nástroj.

\section{Metodologické ukotvení}

Tento článek je zaměřený na obecné zdůvodnění možné př́nosnosti techniky nazývané evolutivní výklad. Než se vůbec začne uvažovat o případném využití, prospěšnosti či nevýhodách evolutivní interpretace právního textu, bude třeba tento typ výkladu metodologicky umístit. Nejde totiž o klasicky předpokládanou metodu, ani její prvek, a to ani ve smyslu tradiční kontinentální metodologie předkládané Carlem Friedrichem von Savignym ${ }^{1}$, ani anglo-americké (resp. americké), o které mluví např. Tomáš Sobek. ${ }^{2} \mathrm{~V}$ obou pojetích je totiž metoda výkladu chápána jako postup, který je natolik určitý, že má potenciál zajistit, aby dosažené řešení právního př́ípadu bylo jednoznačné, jednoduché a předem odhadnutelné, a zároveň usměrňoval interpreta ve snaze k jeho dosažení. ${ }^{3}$

Evolutivní výklad nepatří ani do jednoho z uváděných výčtů. To však ještě neznamená, že nemůže být metodou novou. Velkou překážkou pro ty, kteří by o evolutivním výkladu rádi mluvili jako o metodě ale je, že se celý jeho koncept dá zkonstruovat z jednotlivých částí výše uvedených metod. Metodologicky korektně by se tedy o evolutivní interpretaci mělo mluvit spíše jako o výkladovém směru, než ji označovat za metodu jako takovou.

$1 \mathrm{~V}$ díle System des heutigen römishen Rechts představil jednotlivé interpretační prvky - gramatický, logický, systematický a historický. Pro detailnější zpracování problematiky viz WINTR, Jan. Metody a zásady interpretace práva. Auditorium. Praha, 2013, s. 19. Později byl tento vzorec obohacen o metodu teleologického výkladu (kterou Savigny považoval za nevhodnou) a dále např. metodu komparativní.

2 Konkrétně jde o tři hlavní interpretační směry odvozované $z$ analýzy tř́i interpretačních prvků - textu zákona (textualismus, jehož zastánci se soustředí pouze na právní text a ignorují všechny ostatní vlivy), úmyslu zákonodárce (intencionalismus, při kterém je nejpodstatnější akcentování vůle tvůrců právního textu) a účelu v právu (metoda teleologického výkladu nebo také - purposivismus, který je zaměřený na hledání objektivního účelu v právu). SOBEK, Tomáš. Argumenty teorie práva. Plzeň. Aleš Čeněk. 2008. str. 217-218. Také: SOBEK, Tomáš. Nemorální právo. Praha: Ústav státu a práva. 2010, s. 325.

3 Srov. s WINTR, Jan; Vstupní úvahy o metodologii interpretace práva [online]; VŠEHRD; 11/2010; [cit. 22. 3. 2014] Dostupné z: http://casopis.vsehrd.cz/2010/11/vstupni-uvahy-ometodologii-interpretace -prava/ 
Obecnou charakteristiku evolutivního výkladu lze otevř́t základním poznatkem, a totiž že podstatným znakem evolutivního výkladu je jeho otevřenost, resp. schopnost dynamicky reagovat na měnící se společenská očekávání kladená na právo, vycházející z technického, kulturního a sociálního vývoje společnosti. ${ }^{4}$ Dá se tedy poukázat, a zároveň upozornit, na skutečnost, že při evolutivní interpretaci je právní text pro interpreta pouze vodítkem, nikoli nepřekonatelnou bariérou, která jej pouze a jen stroze limituje. Do kontrastu s tímto chápáním evolutivního výkladu by se dal uvést opačně smýšlející výkladový směr, zaměrující se na co možná největší možnou věrnost původnímu textu autenticitu ${ }^{5}$, o němž bude v krátkosti pojednáno níže.

Při výkladu právního textu vždy začínáme jeho čtením - zkoumáním jeho gramatických zákonitostí, logické stavby, potažmo systematického propojení jednotlivých jeho částí na sebe navzájem i v souvislosti s ostatními souvisejícími texty. Každý interpret právního textu je tedy do určité míry textualistou. ${ }^{6}$ Jelikož ale není možné vázat se pouze a jen na znění, které v čase stagnuje, je třeba zkoumat i intenci, která stála za jeho vytvořením - tedy historické zázemí, kulturní prostředí a sociální vazby tvưrce, které pomáhaly tvořit jeho úmysl. Pokud má ovšem interpret usilovat o zachování co možná nejvyšší míry autenticity textu, nic dalšího již nezkoumá. Případné odchýlení se od specifického znění je přípustné pouze ve smyslu určitých konvencí daného období, či úmyslu, s nímž autor dílo psal. ${ }^{7}$ Zde se nabízí paralela s právním originalismem. Ten Jack Balkin popisuje jako interpretační směr zaměřující se jak na původní smysl textu, tak na uvažování plánu originální zamýšlené aplikace ${ }^{8}$, nebot’ pokud právě ta nebude dodržena, bude textu přikládán význam a plán nový, původně nezamýšlený. ${ }^{9}$ Dalo by se tedy říci, že v př́ípadě

4 V této části metodologického ukotvování vychází autor článku volně ze své diplomové práce na téma: Porovnání interpretace právního textu a hudby. MALANÍK, Michal. Porovnání interpretace právníbo textu a budby [online]. Brno, 2014 [cit. 2015-08-30]. Diplomová práce. Masarykova univerzita, Právnická fakulta. Vedoucí práce Martin Škop. Dostupné z: https://is.muni.cz/auth/th/348679/pravf_m/

5 Srov. s BALKIN, J.M., LEVINSON, Sanford; Interpreting law and music: Performance notes on „The Banjo Serenader" and „The Lying Crowd of Jews" [online]; 1999, s. 7; [cit. 22. 3. 2014] Dostupné z: http://www. yale.edu/lawweb/jbalkin/articles/interp1.pdf; Autoři na tomto místě nehovoří výslovně o interpretaci, ale o performanci - tedy o finální aplikaci. Ta je ovšem tak úzce spojená s interpretací, že pro dosažení kýženého efektu performance nutně zprvu musí být interpretace tvořena na stejném základě. Dále autoři citovaného díla označují jeden směr jako „autentický“, druhý jako „faithful“. „Evolutivní“ sice není překlad přesný, ale zdá se mi vzhledem k jeho obsahu méně zavádějící, než „,věrný““.

Také považuji za důležité zmínit, že dále v textu užívaný „,autentický výklad“ nemá být spojován s klasicky chápaném významu institutu autentického výkladu (tedy závazný výklad poskytovaný zákonodárcem).

6 SCALIA, Antonin a Bryan A. GARNER Reading Law. Thomson/West. 2012, s. 16.

7 Srov. s MARISI, Flavia; Judicial Interpretation and Musical Performing Praktice: A Comparison; University of Milan; Italy; The International Journal of the Arts in Society; Volume 5, Number 5, 2011, s. 293

8 BALKIN, Jack M. Living Originalism. The Belknap Press of Harvard University Press. London, England, 2011, s. 236. ISBN 978-0-674-06178-1. Balkin dále odlišuje pojmy „skyscraper originalism“, který stojí právě na tomto předpokladu a „framework originalism“, v jehož pojetí je takový postup dlouhodobě neudržitelný a v konečném důsledku nesprávný.

9 Tamtéž; s. 39. 
nově existujících nástrojů, zvyklostí a konvencí, které právo může využít a kterých by se mělo řídit, přísně formalistickým výkladovým směrem zaměřujícím se na zachování původního znění a způsobu výkladu v původním chápání textu, by jich interpret stejně nemohl využít k odchýlení se od textu. $\mathrm{V}$ tomto smyslu tedy hovoříme o textualismu a intencionalismu v té nejrigidnější formě. Ani v tomto př́padě, kdy bychom mohli mluvit o „metodě autentického výkladu práva“, to nečiníme, nebot’ se stále jedná o výkladový směr složený z prvků metod již zavedených.

Evolutivní interpretace ale takto rigidní není. Právě naopak. Míra dodržování formálních pravidel gramaticko-logického výkladu, důslednost snahy zachovat originální text v př́ipadech nesouladu s pozdějšími zvyklostmi, potažmo interpretovým nutkáním do něj zasáhnout, je nastavena zcela odlišně. Jedním z primárních nástrojů, kterým interpret opodstatňuje tyto odchylky je komparace. Komparace s novými společenskými potřebami a očekáváními a stejně tak komparace s již existujícími výklady interpretů, kteří s textem manipulovali před ním (typicky jde o rozhodnutí nejvyšších soudních instancí či o rozhodnutí mezinárodních tribunálů). Díky tomu je tento směr interpretačně velmi živý a vývojově nestagnuje. Jde tedy také o kombinaci textualismu a intencionalismu, jako v př́padě uváděném $\mathrm{v}$ předchozím odstavci, nicméně obohacené o originalistické pojetí1 $^{10}$ a o zkoumání objektivního účelu daného právního textu.

Textualismus má pro tento výkladový směr úlohu nositele obsahu. Originalismus zde figuruje jako ztělesnění subjektivně-historického výkladu snažícího se z dostupných zdrojů rekonstruovat historický kontext, původní zamýšlení smyslu a využití textu - obecně má pouze podpůrnou roli, která spočívá ve zjištění výchozího bodu. Objektivně-teleologický výklad má na druhou stranu roli stěžejní, nebot' se snaží nalézt objektivní účel daného právního textu - jeho ideální podobu a smysl - tedy ne stále stejný, neměnný zákonodárcův/autorův původní úmysl, ale jako vyvíjející se objektivizovanou skutečnost. ${ }^{11}$

\section{3 Úloha evolutivního výkladu}

V obecné rovině práva není možné jednoznačně říci, který postup by měl být vždy preferován, který povede k lepšímu pochopení, dokonalejšímu výkladu, nebo pozitivnějšímu přijetí odbornou i laickou veřejností. Na poli práva mezinárodního je ale odpověd' mírně odlišná. Představa, že by mělo být mezinárodní právo tak přísně formalistické, jako vnitrostátní právo některých zemí, je neudržitelná. Právě z důvodu odlišností mezi koncepcemi určitých právních otázek, úsilí o sjednocování právních úprav a stále se zrychlujícím vývojem společenských potřeb a zpřesňováním právních textů je opodstatněné

10 Nyní už spíše ve smyslu „framework originalism“. Viz BALKIN, Jack M. Living Originalism. The Belknap Press of Harvard University Press. London, England, 2011, s. 21/22. ISBN 978-0-674-06178-1.

11 MALANÍK, Michal. Porovnání interpretace prámníbo textu a budby [online]. Brno, 2014, s. 39, [cit. 2015-0830]. Diplomová práce. Masarykova univerzita, Právnická fakulta. Vedoucí práce Martin Škop. Dostupné z: https://is.muni.cz/auth/th/348679/pravf_m/ 
přiklánět se ke směru evolutivního výkladu práva, zejména v otázkách, které procházejí nejintenzivnějšími proměnami. A to navzdory tomu, že evolutivně zaměřeným výkladem se interpret stává více novým autorem, než interpretem.

V mezinárodním právu, co se výkladu mezinárodních smluv týče, hraje prim intencionalismus. I na mezistátní, potažmo nadstátní, úrovni je třeba uvažovat o smlouvách jako o dokumentu vzniknuvším na základě projevené společné vưle stran. Zatímco tedy při výkladu vnitrostátních právních textů interpret usiluje o nalezení či rekonstrukci právní normy (u které dále pátrá po jejím účelu, který by měl být akcentován více, než úmysl tvưrce textu), při výkladu mezinárodních smluv nachází primárně onu původní vůli stran. Konceptuálně (a dosti zjednodušeně) jde tedy o rozpor mezi teleologickou metodou výkladu a intencionalismem. ${ }^{12}$ Je tomu však skutečně tak?

Obecně vzato je možné říci, že jak celé právo, tak každá jeho jednotlivá část slouží nějakému účelu. ${ }^{13}$ Tento účel nemusí být vždy stejný a může se v čase vyvíjet, zatímco původní vưle autora textu, tedy v našem prrípadě - tvưrců smlouvy, zůstává stále stejná stagnuje v čase. Od momentu, kdy byla projevena, se nemění a pokud ano, původní text tuto změnu nezachytí. To samožrejmě neznamená, že jsou smluvní strany odsouzeny plnit na základě textu, který jim nevyhovuje. Existuje řada technik, kterými mohou text fakticky upravit, at' už je na mysli změna smlouvy dodatkem, zavedenou praxí stran anebo právě díky evolutivnímu výkladu textu. Mezinárodní soudní dvưr ve svém rozhodnutí ve věci ve sporu o právo na volnou plavbu po řece San Juan mezi Costa Ricou a Nicaraguou z roku $2009^{14}$ řekl, že určité pojmy, které strany do textu vložily, jsou způsobilé budoucího vývoje (v budoucnu budou moci obsahovat více, než v době sepsánî), čehož si strany musí být vědomy. ${ }^{15} \mathrm{~V}$ tomto smyslu vývoje obsahu jednotlivých užitých termínů by celý text měl být také vykládán. Tím v podstatě mezinárodní soudní dvưr uznal evolutivní výklad jako akceptovatelnou metodu výkladu mezinárodních smluv ve smyslu čl. 31 Vídeňské úmluvy o smluvním právu. ${ }^{16}$ Nejen, že tedy předpokládá, že obvyklý význam užitých termínů ve smlouvě se s časem vyvíjí, říká, že pokud strany takový termín (způsobilý vývoje) použijí, mají v úmyslu být tímto vývojem ovlivňovány.

12 Pro účely tohoto článku se vyhněme problematice skutečného hledání účelu právní normy.

13 IHERING, Rudolf. Law as a Means to an End. Translated from the German original by Isaac Husik. Boston book company. Boston, 1913 [Quoted 17. 5. 2015]. Available [online] at: https://archive.org/details/ lawasameanstoan00jheruoft, s. iiv.

14 International Court of Justice, Judgment in Dispute regarding Navigational and Related Rights (Costa Rica v. Nicaragua), 2009, Dostupné z: http://www.icj-cij.org/docket/files/133/15331.pdf

15 Tamtéž, s. 9.

16 DESIERTO, Diano A. a Colin GILLESPIE. Evolutive Interpretation and Subsequent Practice Interpretive Communities and Processes in the Optional Protocol to the ICESCR. Max-Planck-Institut für ausländisches öffentliches Recht und Völkerrecht. 2013. ZaöRV 73 (2013), s. 549-589. Dostupné z: http://www.zaoerv. de/73_2013/73_2013_4_a_549_590.pdf, s. 555. 
Při psaní těchto ráádků se ale nelze ubránit poznámce, že, byt’ je krásné vytvořit si vlastní, novou metodu výkladu práva, přesně tyto znaky předpokládá už dokonce i formalistický textualismus. Antonin Scalia např. tvrdí, že textualismus pracuje s pojmem „př́pustný význam“ - to znamená, že žádnému slovu, či větě by neměl být přisuzován význam, který ve skutečnosti nenese. ${ }^{17}$ Zároveň ale dovozuje, že př́pustný význam se mění v souvislosti s vývojem jejich chápání. Balkin k problematice interpretace pojmů dodává, že přes ty jednoznačné interpret jít nesmí, co se však týče nejednoznačných pojmů, musí interpret hledat jejich původní význam, který se dále měnil v čase. Může tedy text doplňovat, napomáhat mu prostřednictvím konstrukcí, ale nesmí jít proti jeho významu. ${ }^{18}$ Dostáváme se tedy opět $\mathrm{k}$ původně zamýšlenému plánu aplikace, míry př́pustného odchýlení se od původního textu a jeho účelu. Vhodno podotknout, že principy evolutivní interpretace byly využívány mnohem dříve, než byl tento moderní výkladový směr pojmenován. Také se tím ověruje shora uvedené metodologické zařazení.

Jako podpůrný argument lze uvést další textualistickou myšlenku. Scalia tvrdí, že slova nemají vlastní vnitřní význam. Jejich význam je přisuzován dle toho, jak daný pojem interpretační komunita chápala $\mathrm{v}$ době jeho zavedení a ve svém celém kontextu znamenajî to, co dle rozumných lidí znamenala v době, kdy byla napsána - s vědomím, že obecné pojmy mohou obsáhnout pozdější technologické inovace. ${ }^{19}$ Lze tedy říci, že i tak zarytý textualista, za kterého se Scalia považuje, předpokládá vývoj ve výkladu prostřednictvím užití pojmů, které tohoto vývoje jsou schopny - obecných pojmů. Tedy přesně to, co označuje za základ evolutivního výkladu Mezinárodní soudní dvůr v př́padě sporu o právo na volnou plavbu po řece San Juan mezi Costa Ricou a Nicaraguou z roku 2009. Vážně je tedy účelné používat pojmu, který pouze teoretické uchopení problematiky ztěžuje? V tomto smyslu tedy o nové metodě výkladu hovořit nelze.

\section{Další úhly pohledu}

Tím, že je „evolutivní výklad“ poměrně často užívaným označením, jehož význam je stále ještě neustálený, se nabízí i jiné úhly pohledu - jiná chápání tohoto populárního instrumentu, než ta, která vychází z uchopení neutrality použitých pojmů v čase a nakládání s nimi. Jedním z dalších by mohl být ten, který je svou podstatou značně méně textualistický. Pro ilustraci poslouží i několik odkazů na vybraná rozhodnutí Evropského soudu pro lidská práva.

George Letsas popisuje praktiky Evropského soudu pro lidská práva související s evolutivním výkladem práva jako interpretační metodu stojící na principu morálního čtení

\footnotetext{
17 SCALIA, Antonin a Bryan A. GARNER. Reading Law. Thomson/West, 2012, s. 31.

18 BALKIN, Jack M. Living Originalism. The Belknap Press of Harvard University Press. London, England, 2011, s. 270. ISBN 978-0-674-06178-1.

19 SCALIA, Antonin a Bryan A. GARNER. Reading Law. Thomson/West, 2012, s. xxv, 16.
} 
Evropské úmluvy o lidských právech ${ }^{20}$ (dále jen: „Úmluva“). Tu přitom popisuje jako formu interpretační etiky, stojící na upřednostňováním čtení hodnotícím morální hlediska práv Úmluvou chráněných a sémantickou autonomií užitých pojmů od úmyslů, praktik a dohod smluvních států. ${ }^{21}$ Tento názor opírá o myšlenku, že pouze morální důvody mohou sloužit jako podklad pro určení přednosti mezi konkrétním nebo abstraktním úmyslem tvůrce textu. ${ }^{22}$ Přitom odkazuje na Ronalda Dworkina a jeho myšlenky, ne nepodobné těm, které byly v tomto článku přiřazeny $\mathrm{k}$ Balkinovu framework originalismu. Letsas přitom nadále tvrdí, že tato interpretační etika, na které metoda evolutivního výkladu stojí, odmítá textualismus i intencionalismus jako kvalifikované metody výkladu Úmluvy. ${ }^{23}$

Byt' je to nepochybně nápad zajímavý a Letsas věnoval nemalé úsilí, aby jej odůvodnil a obhájil, stejně se nelze ubránit dojmu, že právě odkazem na myšlenky právního originalismu nejvíc ukazuje skutečnost, že opravdu nejde o nic nového a natolik významně odlišného, co by mohlo být označováno za novou metodu. Originalismus, jak už bylo výše uvedeno, stojí zejména na textualismu a intencionalismu. Letsasův „přínos“ oproti těmto dvěma směrům (morální odůvodněnî) je ve své podstatě ryze purposivistický. To, co reálně Letsas říká je, že by metoda teleologického výkladu měla být upřednostňována před formalistickým textualismem a původním smyslem, který v současné době už může být prŕliš zastaralý. To je ale značně banální myšlenka. ${ }^{24}$ Složitější otázkou je: Jak na to? $\mathrm{Na}$ tu ale tento článek odpověd’ nehledá.

\section{Závěrem}

Cílem tohoto článku bylo poskytnout základní analýzu evolutivního výkladu práva. Charakterizovat jednotlivé prvky a poukázat na situace, ve kterých je používán a jak. Z hlediska klasické (kontinentálně právnî), ani anglo-americké metodologie interpretace nelze považovat techniky evolutivní interpretace za metodu interpretace práva. V celkových souvislostech jde nepochybně o interpretační směr, který kombinuje různé prvky me-

20 LETSAS, George. The ECHR as a Living Instrument: Its Meaning and its Legitimacy. [online] (March 14, 2012). Dostupné z: SSRN: http://ssrn.com/abstract=2021836, s. 24.

21 LETSAS, George. Strasbourg's Interpretive Ethic: Lessons for the International Lawyer. The European Journal of International Law [online], vol. 21, no. 3 C EJIL 2010. Dostupné z: http://ejil.org/ pdfs/21/3/2066.pdf, s. 537.

22 Tamtéž, s. 538.

23 LETSAS, George. The ECHR as a Living Instrument: Its Meaning and its Legitimacy. [online] (March 14, 2012). Dostupné z: SSRN: http://ssrn.com/abstract=2021836, s. 12.

24 To nakonec Evropský soud pro lidská práva dělá už řadu let. V př́padech, ve kterých evolutivní výklad zmiňuje nebo na něj fakticky př́mo odkazuje (viz Např. CASE OF TYRER v. THE UNITED KINGDOM (Application no. 5856/72); CASE of SOERING v. THE UNITED KINGDOM (Application no. 14038/88); CASE OF HASSAN v. THE UNITED KINGDOM (Application no. 29750/09) a mnohé dalšî), ale i v př́padech jiných. 
tod již existujících (a to jak textualismu a intencionalismu, tak i metody teleologického výkladu práva a metody komparativnî). Evolutivní výklad směřuje na chápání právního textu v dynamickém časovém kontextu a akcentování důležitosti chápání neutrálních pojmů v jejich soudobém významu. Právě tato vlastnost z něj činí tak populární techniku na poli mezinárodního práva, a to i před tribunály, jakým je Mezinárodní soudní dvưr či Evropský soud pro lidská práva. Nicméně ani tato míra oblíbenosti nečiní z této techniky něco, čím by praxe významně obohacovala právní teorii. Jde jen o zjednodušující koncept, pro jehož správné chápání musí interpret rozumět obecnějším teoretickým konceptům metodologie právní interpretace, aby se z evolutivního výkladu nakonec nestal instrument, pomocí něhož lze dosáhnout jakéhokoli výsledku si interpret usmyslí. 